
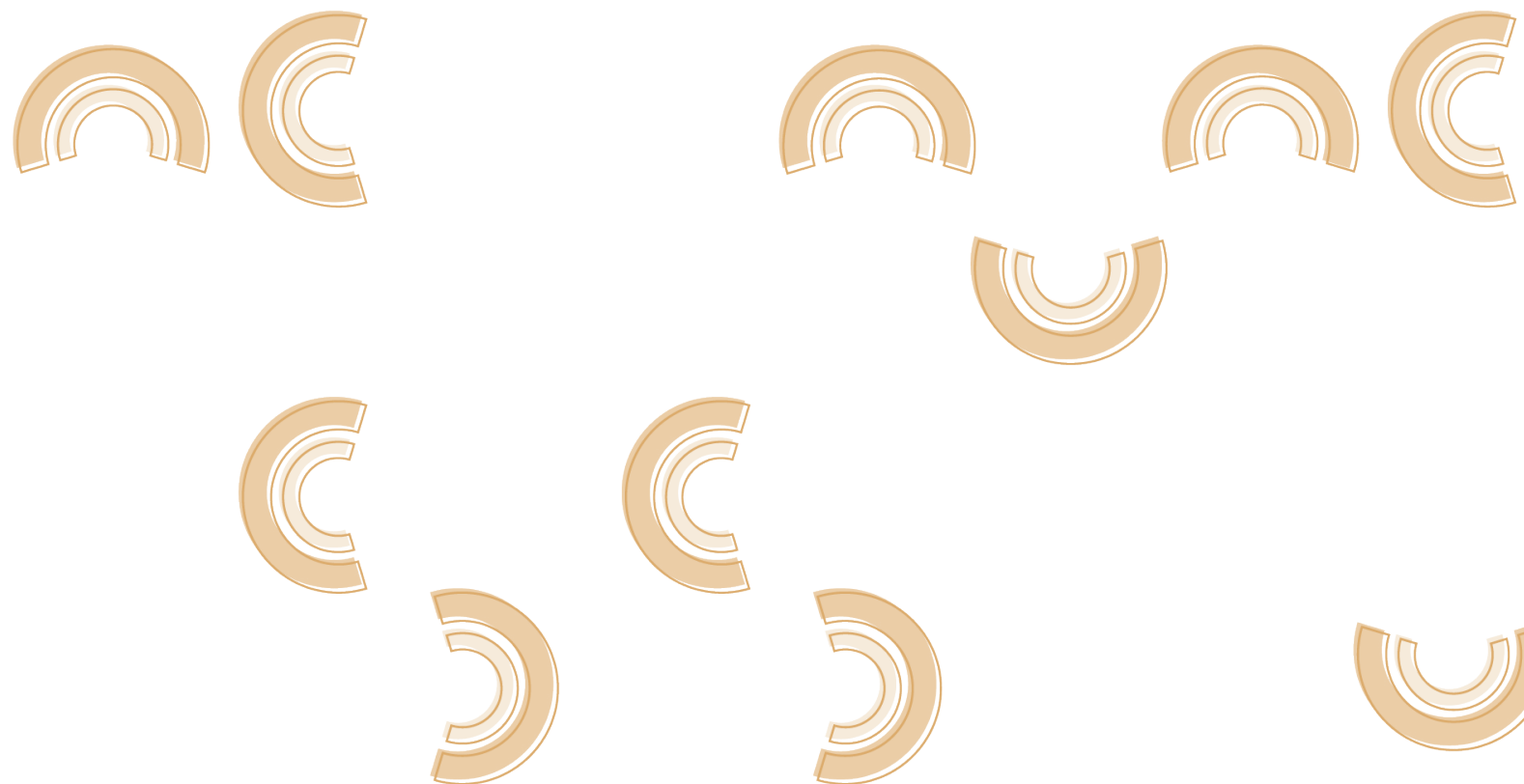

TeXtos e Versões

A MÚSICA E A ENCENAÇÃO, DE ADOLPHE APPIA. PARTE 3.

\title{
Flávio Café
}

Tradução.

Universidade de Brasília

E-mail: cafe.flavio@gmail.com 


\section{RESUMO}

Terceira parte da tradução da obra A música e a Encenação, de Adolphe Appia.

Palavras-chave: Adolphe Appia, Richard Wagner, Ópera, Encenação.

\section{ABSTRACT}

Translation of Adolphe Appia's Musique et mise en scene. Here we present the third part of it.

Keywords: Adolphe Appia, Richard Wagner, Opera, Staging. 


\section{SEgunda PARTE}

\section{RICHARD WAGNER E A ENCENAÇÃO}

o abordarmos a obra dramática de Richard Wagner me parece impos-
sível exprimir mais claramente a situação do que por meio destas pa-
lavras do próprio mestre. Nós veremos que elas são a chave para um problema complexo e que apenas através delas é que nós podemos penetrar na realidade prática do Drama musical, isto é: compreender desde esse ponto de vista prático o fenômeno wagneriano e determinar o caráter das obras subsequentes que garantirão a sua sobrevivência.

M. H. S. Chamberlain, no seu Richard Wagner, expôs de que maneira as mais altas aspirações dos poetas e dos músicos alemães convergiam todas, com maior ou menor grau de consciência, para a ideia de uma obra de arte dramática na qual a poesia e a música se enriqueceriam mutuamente e preencheriam pela sua união as lacunas muito evidentes contidas em cada uma dessas artes isoladamente. Apoiado sobre numerosas citações, M. Chamberlain demonstra de uma forma definitiva que por meio dos dramas de Richard Wagner "uma evolução poderosa, longa de muitos séculos, englobando poesia e música" chegou "ao seu objetivo" ("am Ziel"), que o mestre de Bayreuth realizou o ardente desejo dos seus predecessores e que assim a revelação da qual ele se encarregou pôde ser considerada tanto como a finalização, o apogeu, de um movimento ascendente da Expressão, quanto como o início de uma nova linha de esforços e de desenvolvimento.

Do primeiro desses pontos de vista, a obra dramática de Wagner, testemunhando o desejo dos poetas alemães e a invencível tendência dos músicos dessa raça, então pode incorporar o caráter próprio à produção germânica. 
Esse caráter se exprime com muita clareza na maneira como Wagner chegou a sua plena consciência de artista. Nós sabemos, de fato, que o mestre não conseguiu consumar a união definitiva do poema e da música, tanto que ele considerava o problema como podendo ser resolvido pela descoberta de um procedimento técnico especial; ao passo que ele transfigurou de uma só vez e para sempre a forma do seu drama tomando consciência do objeto que tal união exigia. É preciso então ver nos esforços dos seus predecessores não tanto a procura por uma forma integral da Expressão - a qual eu defino como a procura do procedimento técnico que uniria organicamente a palavra ao som musical - mas unicamente o desejo de libertar o elemento essencial comum a ambas, e exprimir esse elemento de uma forma manifesta.

Em toda obra de arte realmente alemã as preocupações da forma são subordinadas àquelas da Expressão; o que nos faz voltar a dizer que a visão do artista alemão pertence a um mundo onde os meios técnicos são neles mesmos secundários: "Der Deutsche baut Von innen" ["O Alemão constrói do interior"], ele se mune dos instrumento dos quais ele pode dispor no objetivo único de exprimir um objeto que ele só encontra na sua alma. Se essa expressão é bela, será porque o seu objeto é de tão alta natureza que só uma tal forma poderia manifestá-la. Richard Wagner o provou. A forma atinge nele o seu máximo de esplendor em razão da pureza do que ele tem a nos revelar.

Ao abordar uma produção essencialmente nacional, e isso em um estudo tratando de uma questão de forma, é importante estabelecer que a forma é, para o artista alemão, um resultado, e não o objetivo.

Sobre tais disposições, a música deve se desenvolver mais livremente do que qualquer outro ramo da arte, pois sua forma não se encontra em nenhum outro lugar que não na alma do músico. O Drama musical, que tem sua fonte profunda na música, se manifesta irradiando do interior ao exterior; ele testemunha assim uma origem oculta, e sua forma é peremptoriamente e em todo o seu procedimento apenas um resultado: é, portanto, a obra de arte alemã por excelência.

Nesse drama, o texto poético-musical é o único que tem poder imediato e que está sob a impulsão absolutamente pessoal do dramaturgo; contudo, o espetáculo que deve em seguida resultar dele não se enquadra mais no mesmo caso e por consequência ele comporta uma experiência totalmente diferente daquela que podemos adquirir pelo manuseio da língua e da música. De fato, a cultura do olho, do sentimento da forma exterior, entra aqui como fator determinante e necessário à irradiação da música: o que o poeta maravilhosamente fez os nossos ouvidos ouvirem, ele deve poder também evocá-lo aos nossos olhos; esse último procedimento só toca indiretamente o desejo 
íntimo de expressão que deu nascimento ao drama. Ora, o que pode ser o sentimento da forma exterior em um artista para o qual a forma só poderia ser o resultado de uma expressão mais profunda? Evidentemente que nada além de uma questão de contingência; a cultura do seu olho só terá um valor relativo; não se trata, para um Alemão, de sentir se tais formas são belas ou tal espetáculo harmonioso em si, mas somente se a relação entre a Expressão escoada da sua alma e o espaço onde ele faz irradiar essa expressão é uma relação harmoniosa.

Para que o artista possa julgar essa relação, é preciso necessariamente que suas necessidades de expressão e de forma sejam elas próprias harmoniosamente proporcionadas. Richard Wagner demonstra através das suas partituras a prova de uma extraordinária necessidade de expressão, porém, por outro lado, a forma representativa na qual essas partituras nos são oferecidas resulta de um conjunto de circunstâncias complexas onde o desejo do autor não pode se exprimir de uma forma tão clara. Se, então, nós queremos estabelecer a situação de Wagner com relação à encenação, isto é, conhecer a relação que existia em Wagner entre a necessidade de expressão e a necessidade da forma exterior, é preciso começar por libertar dessas circunstâncias a parte das intenções do mestre (tais quais nós as conhecemos pelos seus atos e seus escritos) que pôde manifestar-se integralmente. Em seguida, por meio do princípio hierárquico instituído pela música, nós poderemos determinar o valor da concepção representativa de Richard Wagner e constatar a influência que essa concepção teve de exercer sobre a estrutura do próprio drama. Enfim, em posse de tais dados, teremos permissão para abordar a obra de arte em conhecimento de causa.

Richard Wagner, quando ele procurava realizar o seu drama sobre as cenas de ópera, foi de encontro a impossibilidades que diziam respeito exclusivamente à parte alemã da obra, isto é, a partitura e suas exigências dramáticas elementares. Tendo chegado a sua plena consciências de artista ele renunciou a representar seus dramas sobre uma cena de ópera e quis construir-se uma ad hoc.

Seria a forma representativa que essas cenas podiam lhe oferecer que não mais lhe convinha? Não. Ao contrário, é um estado social que se opunha a todos os seus esforços, um estado social que arrastava consigo a corrupção completa do que nós chamamos de Arte, e em particular da arte dramática, e trazia também a incompetência do público tanto quanto a dos seus executantes. Se o vício que o mestre combatia só tivesse sido uma questão técnica, ele, sem dúvida, o teria vencido com a energia inconcebível da qual ele era dotado. Mas Wagner é um gênio essencialmente alemão; a forma, para ele, 
deveria resultar de um estado de coisas e não poderia ser estabelecida artificialmente por ela mesma.

Em Bayreuth, onde o mestre fez o esforço supremo de criar ao menos em símbolo o estado de coisas impossível, não são as condições formais da representação que alteram, aos seus olhos, o valor do resultado obtido, mas sim que o público não conseguia encontrar esse símbolo para provar dele. Quando consideramos a vida de Richard Wagner à luz dos seus escritos, descobrimos que nunca foram as condições formais já existentes que se opuseram à execução da sua obra, mas somente o estado da sociedade na qual essa obra tinha que viver. Por exemplo, quando um meio favorável pode ser artificialmente criado, do ponto de vista unicamente dramático, em um auditório, e por uma noite - quando da primeira representação de Tristão e Isolda em Munique - não vemos Wagner tendo que reclamar dos meios representativos de cujos quais ele dispunha; pelo contrário, sua satisfação nesse aspecto permite chamar essa representação (assim como M. H. S. Chamberlain o faz) o primeiro Festpiel alemão.

O mestre estimava então que a manifestação clara e precisa do seu drama era possível nos dados representativos atuais; e quando ele veio a construir o Festspielhaus de Bayeuth, foi sobre esses dados que ele concebeu tudo o que concerne à cena ${ }^{2}$.

Nas novas condições, ele só viu que a música impõe as consequências puramente dramáticas à ação do drama e é a elas que se limitam as reformas que ele introduziu no espetáculo; quanto às condições formais que, nós o sabemos, resultam da duração musical, delas ele não se ocupou e inclusive parece tê-las completamente ignorado até agora. A cena de Bayreuth, apesar dos seus importantes e muito numerosos defeitos, é a única a poder nos dar uma demonstração convincente das reformas do mestre, mas essa mesma cena nos prova também que a distinção que nós acabamos de fazer entre as condições formais e as consequências puramente dramáticas do Drama musical, longe de ser um vão argumento teórico, pode se tornar uma realidade tangível e dolorosa: tudo o que emana diretamente do desejo íntimo e profundo de expressão no artista alemão é as vezes manifestado em um grau de perfeição incomparável com qualquer outra coisa; por outro lado, a falta de compatibilidade entra a partitura e a forma representativa, cuja realização material não emana diretamente das intenções do artista alemão, dá ao espetáculo um valor artístico tão inferior àquele do texto poético-musical que a integridade do drama é definitivamente atingida durante a representação.

Sabemos que Wagner construiu o seu Festpielhaus para a representação do Ring. Portanto, do ponto de vista técnico, a existência dessa cena desti-
1 Da mesma forma que os obstáculos materiais que se opuseram a essas primeiras representações parecem se ater mais ao estado precário dos elementos heterogêneos que se tinha que reunir do que à própria natureza desses elementos.

2 Eu faço aqui abstração da disposição particular do auditório e da orquestra no Festpielhaus, pois ela só tem uma relação indireta com a forma do espetáculo. 
nada a esse drama especial não pode nos deixar dúvidas sobre as intenções representativas do mestre. Todavia, poderia acontecer que, lá mesmo onde a sua vontade parecia comandar soberana, o mestre foi obrigado a assumir compromissos mais ou menos consideráveis. Importaria então saber quais eram suas opiniões teóricas na época quando, em plena maturidade, ele se encontrava, entretanto, por circunstancias particulares, o mais distante de toda realização efetiva, pois este, evidentemente, o momento onde o seu desejo de artista deveria estar o mais liberto possível das influências paralisantes da realidade material.

Dois dos principais escritos de Wagner datam de tal época; eles carregam um caráter definitivo e se encontram tão misturados à concepção do Ring que eles quase fazem parte dele. Eu quero falar de Das Kunstwerk der Zukunft e de Oper und Drama ${ }^{3}$. Esses escritos são de uma riqueza incomparável, também não tenho a pretensão de resumi-los aqui, ainda mais que seu alcance geral ultrapassa em muito o ponto de vista do presente estudo; mas ambos beneficiam da existência do drama ao qual eles estão tão estreitamente ligados e possuem, portanto, mais do que qualquer outro, a natureza de revelar as disposições do mestre. Por eles nós poderemos completar teoricamente as noções cuja cena de Bayreuth testemunha e comprovar sua autenticidade. É óbvio que eu só posso extrair as passagens cuja aplicação exclusivamente técnica permanece independente das ideias de futuro características do pensamento do Wagner.

Em Das Kunstwerk der Zukunft, Wagner coloca em princípio que a existência normal do novo drama será o desabrochar supremo de um estado de cultura que não comportará mais a reprodução do corpo humano pela escultura e a pintura.

"Se o homem, na vida, faz homenagem ao princípio da beleza, se ele torna belo seu próprio corpo, se ele se regozija dessa beleza manifestada pelo seu corpo, o assunto e a matéria artística da reprodução dessa beleza e (o objeto) da felicidade para essa beleza são indubitavelmente o próprio homem, vivo e perfeito; sua obra de arte é o Drama, e a redenção da plástica é precisamente o desencantamento da pedra, (o retorno) ao homem em carne e osso, (a passagem) da imobilidade ao movimento, do monumental ao atual. (RW. III, 201)."

"É impossível que a pintura representando os homens tenha uma vida normal, necessária, lá onde, sem pincel nem tela, no quadro mais vivo, o mais artístico, o próprio homem belo se represente em perfeição." E o mestre acrescenta: "A pintura de paisagem, conclusão última e perfeita de todas as artes plásticas, se tornará a alma verdadeira e vivificadora da arquitetura; ela nos ensinará a vestir a cena para a obra de arte dramática do futuro; e nela ela re-
3 Sabemos que a concepção definitiva do Ring é posterior à redação desses dois escritos. Eu não pretendo, portanto, fundar aqui uma demonstração sobre um gênero de simultaneidade que essas datas certas contradiriam, mas sim sobre a íntima relação que existe no artista entre a consciência racional da sua arte e a livre execução da sua obra. 
presentará a si mesma, de uma maneira vivificadora, o plano de fundo da natureza para o homem vivo, e não mais forjado. (RW. III, 212-3)."

Mais adiante, Wagner insiste sobre a vantagem considerável que o paisagista encontrará nas suas novas relações com a obra de arte suprema: "O que o pintor paisagista força a entrar no quadro estreito da cena, no seu desejo de fazer conhecer o que ele viu e adquiriu, (...) ele preencherá doravante no vasto quadro da cena trágica; ele transformará todo o campo da cena em um testemunho da sua força que cria a partir da natureza. O que ele só podia esboçar pelo pincel, na mistura de cores mais complicada, para fazer ilusão, ele tornará tangível por um judicioso emprego artístico da luz, para produzir uma sensação perfeita de ilusão. A rusticidade aparente dos seus engenhos artísticos, a aparência grotesca dos seus procedimentos, na pintura dita decorativa, não molestarão; pois ele considerará que mesmo o pincel mais delicado ainda é uma humilhação para a obra de arte perfeita, e o artista só pode orgulhar-se quando ele é livre, isto é quando sua ora de arte é acabada e viva, e que ele se entregou a ela, ele e todos os seus acessórios. Mas a obra de arte perfeita, que se apresenta a ele sobre a cena, nesse quadro e frente a coletividade do público, vai satisfazê-lo infinitamente mais do que a sua criada no passado com instrumentos mais distintos; ele certamente não terá que se arrepender de ter se servido do auditório de teatro em proveito dessa obra de arte, sobre pretexto de que ele podia outrora dispor em discrição da superfície unida de um pedaço de tela: pois sua obra, em último recurso, permanecendo imutável, qualquer que seja o quadro no qual a vemos, contanto que ela o faça compreender o assunto, sua obra de arte causará sempre, nesse quadro, uma impressão mais viva, uma inteligência maior, mais geral, que a paisagem de outrora (RW. III, 220-1)."

A pintura, posta no mesmo nível que a escultura no que concerne a reprodução do corpo humano, é uma noção que contém não exatamente um erro teórico, mas um defeito técnico muito importante. A existência da pintura é infinitamente mais complexa do que Wagner parece supor e, sobretudo, infinitamente mais contingente do que a escultura. A cena dramática não constitui um equivalente para a vida particular da pintura enquanto tal, e ainda menos uma transfiguração plausível; pois o corpo humano, vivendo no espaço, não tem relações normais com as cores distribuídas sobre uma superfície qualquer, e apenas a presença desse corpo, independente de um entorno ao qual ele possa participar, não tem nada em comum com os objetos da pintura. ${ }^{4}$ Quando Wagner considera a pintura de paisagem como se tornando "plano de fundo vivo e quente para o homem vivo e não mais forjado", ele parece tomar consciência da impossibilidade técnica dessa fusão e as conclusões
4 Já tratei desse assunto na parte precedente desse estudo; então, para lá remeto o leitor para mais amplas reflexões. 
decorrentes da mesma, tão errôneas quanto sejam do ponto de vista absoluto onde ele se encontra, não deixam de ser pertinentes no nível da aplicação prática. Mas em diversas reprises o mestre considera essa fusão como possível; como por exemplo na passagem: "Contanto que esteja em seu poder, este (o mímico) deverá manifestar à vista do homem interior o que ele quer e sente. É a ele que pertence, em todo o seu entendimento e sua profundeza, a superfície da cena, onde ele mostra a sua forma e o seu movimento por meio da representação plástica (...) (RW. III, 224).”

Ou então: "através ele (o pintor de paisagem), a cena se torna inteiramente uma verdade artística: seu desenho, sua cor, o emprego que ele faz da luz, fazendo nascer uma impressão tão viva e tão quente, obrigam a natureza a servir a suprema intenção artística. (RW. III, 220)”. Doutra parte as duas noções - plano de fundo e fusão - estão misturadas: "Da mesma forma que a arquitetura e, sobretudo, a pintura cênica de paisagem podem colocar o artista dramático na ambiência da natureza física e podem lhe dar, (de forma poderosa) por meio da fonte inesgotável dos fenômenos naturais, um fundo sempre rico e sugestivo, - da mesma forma a orquestra, esse corpo vivo de harmonia infinitamente variada, foi dada ao indivíduo ator, como a fonte inesgotável de um elemento natural, de uma arte quase humana (RW. III, 225-6)."

Aqui vem acrescentar-se a ideia de orquestra moderna: "ela (a orquestra) revolve, por assim dizer, o solo árido, imutável, da cena real em uma superfície móvel, flexível, maleável, etérea (...)" (RW. III, 226.) Ora, o mestre não parece compreender pelas últimas palavras uma efetiva equivalência entre a flexibilidade da orquestra e aquela do espetáculo, mas somente o papel da orquestra como tal, com relação à irremediável rigidez da matéria.

Em Oper und Drama, no qual a influência obsessiva do Ring se faz sentir mais vivamente, as noções representativas factuais são quase totalmente ausentes; todo lugar está ocupado por uma recapitulação histórica correspondendo à primeira metade do título, e por um desenvolvimento teórico, muito considerável e minucioso, que trata da nova forma dramática exclusivamente nas suas relações diretas com a concepção e a composição do texto poético-musical, sem tocar por isso no princípio cênico. A partitura, e mais particularmente a declamação cantada do ator, atém-se naturalmente, de tão perto, à presença dos personagens sobre a cena que essa porção do espetáculo é frequentemente abordada, mas sem estender-se, todavia, até os outros fatores representativos; parece que Wagner sentiu que um princípio cênico correspondente à sua demonstração poético-musical fazia falta nele, e que ele abordou o mais rapidamente possível essa parte do drama. Em contrapartida, as citações que eu venho de fazer de Das Kunstwerk der Zukfunt testemunham 
uma lacuna técnica muito caracterizada para nos permitir afirmar que o mestre esteve consciente da falta de equivalência entre a sua criação dramática e suas intenções representativas, e nós nos vemos forçados a concluir que foi por causa da insuficiência totalmente germânica da cultura do olho, insuficiência que se manifesta em Wagner por uma falta de congruência entre a sua visão formal exterior e seu poder de expressão. A importância enorme que o mestre confere ao ator - ao ator isoladamente - é um resultado direto dessa situação, pois é de se ressaltar que essa importância não é de ordem hierárquica; Wagner não considera o ator como o primeiro e único grau entre a partitura e os fatores inanimados da cena; mas quando ele realizou sua concepção pelos meios poético-musicais e comunicou ao ator o seu papel, ao invés de determinar por este último as inter-relações dos outros fatores representativos, ele volta ao conteúdo inteligível do poema para ditar de lá, e sem passar necessariamente pelo ator, o lugar da ação. Ele se afasta assim da necessidade orgânica da sua obra, e é provavelmente o caráter arbitrário de uma tal encenação que o impediu de delimitar definitivamente a sua regência, ou ao menos de publicá-la.

Disso, resulta um conflito inevitável, pois o poder de evocação de que Wagner dispunha o impeliu a exprimir vez ou outra a união dos personagens com o seu meio; o poeta-músico oscila então entre a toda poderosa intensidade do seu gênio e a insuficiência dos seus meios representativos. O que nomeamos correntemente as exigências exorbitantes de Wagner para a encenação dos seus dramas e as artimanhas de força que ele exigia do maquinista, do cenógrafo e até mesmo do ator não é nada mais que o resultado de uma intensidade de expressão desproporcionada feita com procedimentos cênicos com os quais, todavia, ele teve de se contentar na sua própria concepção. Uma estando mais forte do que a outra, ela vence sempre e cria assim dificuldades intransponíveis para a realização integral dos seus dramas por meio da encenação atual.

Nós estabelecemos que teoricamente e praticamente a concepção representacional de Richard Wagner não diferia no seu princípio dos procedimentos cenográficos em vigor nos nossos teatros. Mas como a falta de congruência entre a partitura e a encenação teve necessariamente que estender sua influência até a própria concepção dramática, é preciso primeiro procurar qual influência um dado grau de desenvolvimento no sentimento da forma exterior pode ter sobre um grau de poder expressivo, pois nós não poderíamos abordar os dramas do mestre antes de ter elucidado esse ponto delicado.

O poeta-músico, ao compor a partitura do seu drama, não está sendo sugestionado por alguma visão formal? Evidentemente, todo dramaturgo deve evocar na sua imaginação a visão dramática da ação que ele desenvolve; não é a isso que 
eu me refiro, mas sim de um transposição efetiva dessa visão no espaço, em um lugar cujas condições são consideradas como podendo fornecer uma atmosfera viável à ação cênica. Não se pode por em dúvida que o dramaturgo que compõe seu drama para ser representado, e somente para isso, o transporta instintivamente para um espaço cênico dado. ${ }^{5}$ Se ele se serve da música, as exigências de duração, mesmo unicamente para a ação dramática, lhe impõem uma visão mais precisa do que se ele se servir apenas da palavra. Quando então ele aceita um espaço que lhe é dado por uma convenção estranha a sua obra, o dramaturgo testemunha por conta disso que a música não lhe parece poder ditar peremptoriamente a forma representativa, o que nos faz voltar a dizer que ele ignora que a música o faça. Quais serão as consequências dessa atitude para o poeta-músico? Primeiramente, em todo lugar onde o espaço da cena se impor a ele, ele será forçado a fazer depender deste, por tão pouco que seja, sua composição poético-musical; em segundo lugar, lá onde, impelido pelo seus poder de expressão, ele perder a cena de vista, sua concepção oscilará entre as imagens que a sua fantasia mais ou menos cultivada puder lhe fornecer e o jogo da livre expressão poético-musical cuja corrente muito rápida o impedirá de fixar sua visão.

A situação de Richard Wagner com relação à encenação é dessa forma totalmente expressa; pois é incontestável que as condições formais das nossas cenas pareçam aceitáveis ao mestre e suscetíveis de reformas não nos seus princípios, mas somente nos seus empregos e que ele próprio pôs, sobre a cena de Bayreuth, seu drama do Ring. Por consequência a cultura do olho não era em Wagner sensivelmente mais desenvolvida que a cultura visual a qual corresponde o princípio da encenação atual e essa encenação não fazia, portanto, violência a sua visão pessoal.

Mas uma cultura superior do sentimento da forma guia não somente a escolha dos meios, mas sobretudo o seu emprego racional. Ao adotar para o seu drama uma forma representativa convencional, Wagner testemunhou um tipo de defeito que explica como ele pôde desprezar até o limite o procedimento cenográfico de nossas cenas modernas. A fantasia de um tão formidável evocador de fato teve que se extraviar para a via do realismo cênico e pediu do espetáculo certos recursos que a arte não pode utilizar sem grandes sacrifícios: a pintura e a escultura renunciaram ao movimento; a poesia só se dirige ao nosso entendimento; a arte cênica está submissa às leis materialmente restritivas da expressão e do signo. Nós concebemos que esses motivos, ao se imporem, em todo o seu realismo, à visão de um Richard Wagner, forneceram uma intensidade poético-musical excepcional; mas o transporte dessa intensidade sobre a cena teve que se revestir ou de um caráter musicalmente expressivo não correspondente à intenção poética realista que sugestionou di-
5 A inferioridade de muitas peças modernas onde o autor procurou na sua própria concepção a perfeita harmonia representativa deve ser atribuída ao estado rudimentar e convencional da encenação sobre nossos teatros. Nesse caso o artista vulgar sabe acomodar sua visão aos procedimentos de que ele pode dispor; o artista delicado prefere disso se desligar o máximo possível e se torna então "literário" e não dramaturgo; 0 artista totalmente superior renuncia tanto a um quanto ao outro. 
retamente o músico, ou então de um caráter simplesmente simbólico em contradição com a vida musical; e, assim, ou é o poeta que sofre pela impossibilidade ou ele renuncia a evocar a parte contingente da sua visão, ou, então, o que é pior, o músico deve renunciar à expressão representativa para se aproximar do signo exigido pela sugestão poética ${ }^{6}$. Por outro lado, o esquecimento de todo espetáculo perante o fluxo invasor da expressão onde o poeta-músico se sente o mestre absoluto seria evidentemente mais favorável à obra de arte se o princípio cenográfico convencional não impedisse a música de se transportar pela via hierárquica sobre a cena. Já que Wagner ignorava as leis técnicas da hierarquia representativa, ele estava, portanto, tentado a perder de vista a realização cênica em toda parte onde o seu drama comportava um largo desenvolvimento interior. De forma que o mestre sacrifica constantemente a existência representativa das passagens que, aos seus olhos, são, todavia, as mais importantes do drama. O seguimento consecutivo dos motivos realistas aplicáveis (ao menos nos seus princípios) à cena moderna, e dos motivos de pura expressão, inconciliáveis com essa cena, alteram gravemente o alcance do espetáculo oferecido aos nossos olhos, e nos pede um trabalho de reconstituição contrária às intenções essenciais do Drama musical.

Aqui está o ponto mais crítico da encenação dos dramas de Wagner7. Nós vemos como a desproporção entre o sentimento da forma exterior e o poder de expressão, ao agir diretamente sobre a concepção do drama, pode perturbar a harmonia dos fatores poético-musicais e espalhar, por meio do espetáculo, a sua influência desestabilizadora até o próprio público.

Para que uma obra de arte seja harmoniosa em todas as suas partes, é preciso que ela possa encontrar um meio social favorável a sua manifestação; em outros termos: suas condições de existência devem ser fornecidas pelo seu meio social. Ora, isso implica sempre em uma concessão mais ou menos considerável e mais ou menos inconsciente feita a gosto. A pintura da renascença italiana nos dá o exemplo ${ }^{8}$. A harmonia é ao preço dessa incontestável decadência. Nós sabemos que o drama wagneriano deve sua existência à intransigência sempre mais marcante do mestre para com a cultura artística dos seus contemporâneos. Era preciso, portanto, que a obra fosse dotada de uma intensidade prodigiosa; pois não se tratava de uma sublime interpretação do pensamento contemporâneo, tal como Rafael a apresentava aos de sua época, mas sim uma revolução sangrenta tais como um reformador provoca fatalmente pelos seus discursos. Esse poder deveria ser, como sempre, expiado, e é ao preço da Harmonia que Wagner propagou vitoriosamente em todo o mundo sua mágica vibração, ao preço da Harmonia que uma obra menos poderosa teria que adquirir para fazer o mesmo caminho.
6 Eu já toquei nesse assunto na parte anterior.

7 Desse dilema, nossas cenas modernas fazem pouco caso: impotentes para opor o Signo à Expressão já que a convenção cênica destrói o caráter tanto de um quanto do outro, elas se contentam em nivelar arbitrariamente todos os motivos da representação, o que equivale a não satisfazer nenhuma das exigências do dramaturgo.

8 E, em um campo totalmente outro, certos teatros de gênero em Paris. 
Nos nossos dias, a obra de arte, para ser harmoniosa, deve ser o produto do egoísmo artístico: é por um desejo totalmente pessoal que o artista pode vencer a hostilidade ambiente da nossa sociedade tão refratária a qualquer atividade artística e fazer seja um meio de expressão de fato, seja uma repulsa favorável ao efeito que ele quer produzir. Supondo que um semelhante desejo possa ir de par a par com o poder de um Richard Wagner, nós poderíamos afirmar que, então, o mestre teria se aproximado sensivelmente da forma representativa normal exigida pelos meio de expressão dos quais ele se serviu. Tal não foi o caso. Sua obra, mesmo antes de ter plena consciência da sua missão, foi uma obra de devoção tácita; a responsabilidade esmagadora que incumbia o mestre pela natureza do seu gênio o impeliu dia após dia para uma via onde o artista só podia se mutilar dolorosamente. Os sonhos maravilhosos do seu pensamento otimista o sustentaram por muito tempo. Embriagado pela única possibilidade da sua realização, Wagner encontrava a força de edificar os colossos que nós admiramos; mas seus materiais, ele, todavia, os tomava na Realidade; nessa realidade que obriga todos aqueles que querem nela aparecer a mil compromissos. Bayreuth encarna esse majestoso dilema; e se a idealidade de um tal símbolo é um bem sem preço, sua realização material nos permite sentir no mais íntimo do nosso ser o drama infinitamente trágico que representa a aparição artística de um homem tal como Richard Wagner.

Assim, o caráter da expressão poético-musical dos dramas de Wagner está em desacordo não somente com os meios atuais de representação, mas também, o que é mais grave, com as exigências formais do autor. A factibilidade da visão cênica pessoal a Richard Wagner, com relação ao poder poético-musical do mestre, pode então ser contestada.

Essa afirmação não seria por demais irreverente perante um dos maiores gênios que jamais existiram, e o respeito não pediria de preferência uma confiança absoluta na alta Besonnenheit [sabedoria] do dramaturgo?

Depois de ter constatado teoricamente uma tão importante lacuna, seria preciso frear-se de querer preenche-la antes de procurar de alguma forma a sua justificação, não mais por considerações gerais e biográficas, mas pela contemplação exclusiva dos dramas em questão. É o que eu vou tentar fazer.

Uma coisa fica clara desde o início: é o idealismo do drama wagneriano. Quer dizer, a ação cênica, ou seja, o espetáculo, encontra-se em vista da expressão musical (mãe do drama) no papel de "alegoria com relação ao seus significado"9. Não que a música se encontre de uma lado e o espetáculo de um outro, mas assim Wagner se exprime: "Wo die ander Künste sagen: das bedeuet, sagt die Musik: das ist." ["Lá onde as outras artes dizem: isto significa, a música diz: isto
9 H. S. Chamberlain, no seu Drama Richard Wagner's nota esse fato; para lá eu remeto o leitor. De resto eu já tratei dessa questão sob uma outra face na parte precedente. 
é."] A música, ao acompanhar o fenômeno, apenas exprime, todavia, a sua "essência íntima". A natureza da sua expressão é assim eterna, em oposição ao caráter contingente de qualquer ação dramática. O Drama musical é então, pelo emprego da música, uma obra necessariamente idealista. De onde resulta que o acordo entre a intensidade poético-musical e a intensidade representativa não é uma questão de valor em si, mas, como nós vimos, de circunstância; a qualidade do espetáculo não está em função de uma qualidade análoga no texto poético-musical, mas é o texto que, submisso à leis de uma ordem superior, dita a natureza do espetáculo que ele comporta. Ora, a idealidade do texto poético-musical não implica que a sua realização sobre a cena seja indiferente do meio, assim talvez poderíamos supor; ela também não implica que a composição do espetáculo possa efetuar-se com base em dados estranhos à partitura. Se fizermos abstração das obrigações hierárquicas que nós conhecemos, para ser percebido integralmente, esse idealismo deve ter previamente afastado da encenação tudo o que teria um caráter contingente com relação ao texto poético-musical, pois a única noção contingente que nós devemos conservar na representação do Drama musical é a própria ação cênica; nós deveríamos poder, de lá, alcançar de um salto só o sentido eterno dessa ação, aquele que a música nos revela; nosso prazer estético consiste em nos mover livremente entre esse dois extremos. Se o espetáculo já fornece por si só um motivo para oscilarmos, como é o caso quando ele é composto de elementos inúteis e estranhos ao espetáculo, nosso campo aumenta de uma forma desfavorável, e nos dá um caminho a traçar antes mesmo que nós possamos atingir a simples ação cênica, a qual é, contudo, a noção primeira. Pelo fato do drama se manifestar em uma dimensão temporal, acontece, então, essa coisa lastimável da qual nossos olhos, requisitados pelo espetáculo, procuram dele extrair a ação, enquanto que a Reveladora, a Musica, reverbera veemente nos nossos ouvidos; nós a entendemos bem, nós até a escutamos, mas, incapaz de nos manter para além do evento cênico, nos a aplicamos tacitamente ao espetáculo e somos desorientados pela sua intensidade desproporcionada.

A encenação do Drama musical tem, portanto, uma extrema importância já que o idealismo que é a essência desse drama só se manifesta com constância sob a condição de encontrar no espetáculo um aliado.

Wagner estava bem convencido da importância da encenação (mímica e cenografia) no seu drama, a disposição do seu Festspiel haus comprova isso. Não obstante, coisa curiosa, esse gênio perfeitamente idealista não o era no que concerne o sentido da visão; ele deslocava o sentido da importância cênica. Infiel sem o saber ao princípio de unidade que regia a sua obra, ele considerou o olho como um sentido realista ao qual, por consequência, o dramatur- 
go deve se dirigir por meio de uma realização material independente e o liberta de toda responsabilidade para com a expressão ideal da música e a intensidade muito particular que implica essa expressão.

É bastante provável que, do ponto de vista psicológico, o poder intenso que o mestre desenvolveu nas suas partituras não poderia se realizar sem um contrapeso realista qualquer. O defeito representativo seria assim, em Wagner, o inverso do seu prodigioso poder.

Contudo, acontece que o idealismo transcendente do drama wagneriano, ao invés de sugerir ao seu criador uma forma representativa adequada, o empurrou mais ainda para uma concepção cênica estranha à revelação musical e a qual o princípio atual da encenação não oporia, portanto, obstáculos sérios no seu cerne. Se, de uma parte, o mestre não tivesse dado pela construção da cena de Bayreuth o seu assentimento ao princípio cenográfico atual, e se, em contrapartida, ele não tivesse provado nos seus escritos, e provavelmente nas suas palavras, que a forma representativa apta a realizar a sua obra se encontrava ainda na infância, nós não teríamos nenhum direito válido para apoiar nossa afirmação no que o concerne, e nós deveríamos limitar nossas observações apenas a suas obras, tomadas isoladamente, ao risco de lhes submeter uma violência extrema. Felizmente, o próprio mestre nos poupa dessa alternativa.

Contudo, a situação é tão complexa que seria desesperador nunca poder representar convenientemente os dramas de Richard Wagner se nós não tivéssemos adquirido um princípio diretor independente do poeta-músico ${ }^{10}$. Mas esse princípio goza realmente de uma tal independência? A hierarquia representativa é fatal e deve ser aplicada qualquer que seja a concepção cênica do autor?

A priori, parece bem que seja assim, e nós conseguimos sem escrúpulos estabelecer esse princípio na parte precedente. Conquanto, no nosso caso a obra de arte existe; nós não podemos fazer nada sem ela. Consultemo-na então e, para não complicar nossa tarefa, só consideremos os dramas do segundo período, aqueles cujas circunstâncias biográficas não virão atrapalhar nosso julgamento.

Todo artista sincero sentirá o quanto esse exame é delicado e quanto risco ele corre de conter um atentado sacrílego à obra de arte menos feita para a análise racional. Eu queria inspirar suficiente confiança para que o leitor me seguisse sem muita repugnância nessa via perigosa. Talvez o resultado possa me justificar?

Tristão, Parsifal, o Ring, Os Mestres cantores são dramas que se opõem tanto uns aos outros que é possível, antes mesmo de considerar cada um isoladamente, perceber o seu caráter individual. 
Em Tristão, nós nos encontramos desde o início no seio de uma ação totalmente interior: o primeiro ato é como o último brilho do mundo material e sensível; no segundo ato o limiar é atingido, a porta fechada. A atmosfera misteriosa desse além só nos pode ser comunicada através da música, e o próprio Wagner diz que aqui "só se passa a falar propriamente de música". Essa música é interrompida no fim desse ato, e ao curso do seguinte, por frias claridades que penetram, como por fissuras, do domínio da lei mortal e arbitrária naquele do eterno, só e único desejo.

Em Parsifal, o espetáculo consiste em uma série de situações diversas que estão lá pela única finalidade de determinar na alma do herói puro e inconsciente uma operação milagrosa; Parsifal se torna então consciente dele mesmo, e, pela sua castidade, pôde entender tão cedo o seu saber sobre todo ser vivo: a solidariedade suprema lhe é assim revelada.

No Ring, a operação interior é não somente de uma natureza muito mais complexa, mas ainda ela acontece na alma de um deus; de forma que ela emana desse deus e se multiplica nas suas criaturas. A parte episódica adquire por esse fato uma importância característica e obriga a ação dramática a estendê-la consideravelmente.

Em Os Mestres cantores, a ficção cênica é apenas um pretexto, ela não constitui o drama. O poeta-músico quis nos comunicar o triunfo constante e completo que uma personalidade elevada consegue sobre a aparente fatalidade dos egoísmos acumulados. O procedimento que ele emprega para esse fim é dos mais admiráveis: o mestre permite que a vida excitante dos pequenos interesses pessoais tome todo o lugar; então ele dota à expressão musical dessa vida de uma intensidade e de um esplendor incomparável sem, todavia, transfigurar de forma alguma suas manifestações materiais. Enfim, para justificar esse paradoxo e colocar em dia o seu pensamento, ele faz do seu herói, Hans Sachs, uma alma contemplativa de poeta; de onde resulta, por um conjunto de toques infinitamente hábeis, que a intensidade da expressão fica por conta da natureza particular dessa alma $^{11}$. Assim, desde a primeira nota do drama até a última, o conflito e o triunfo são exprimidos simultaneamente: um pela ação material em contradição com o poder de vibração que ela estabelece, a outra pelo único fato desse poder. Não suponho, vai de si, que essa combinação foi inteiramente consciente em Richard Wagner; é impossível distinguir em uma obra tão eminentemente genial qual a parcela de efetiva reflexão que concebeu sua composição. Então, eu apenas constato o que a obra de arte testemunha por ela mesma, sem entrar, nem um pouco que seja, no domínio pessoal do criador.

Nós vemos que há dois, desses quatros dramas, respectivamente Tristão e Os Mestres cantores, cuja forma representativa geral resultava necessaria-
11 Como muitos outros elementos nesse estudo, toda essa concepção de Os Mestres cantores é inspirada por Le Drame wagnerien de H. S. Chamberlain. 
mente da intenção dramática, e cujo o detalhamento, apenas, poderia apresentar alguma contradição. De fato, para Os Mestres cantores, a continuação realista dos fatos não poderia ser interrompida sem falsear a relação particular onde se encontram os diversos fatores desse drama; e em Tristão é a redução suprema de toda atividade cênica em favor da livre expressão do drama interior que realiza mais claramente a concepção particular do dramaturgo. Por outro lado, o Ring e Parsifal deixam à concepção representativa do mestre o mais vasto campo de invenção.

No drama falado, a natureza e a continuidade dos episódios devem se revestir das formas da nossa existência inteligível. Nela, a invenção do dramaturgo é, portanto, estritamente limitada à ordem realista procedendo de causa a efeito; enquanto que a ação de um drama inspirado pelo desejo musical repousa sobre intervalos temporais que, nós o sabemos, não são mais rigorosamente comandados pela causalidade. O desenvolvimento da expressão musical obedece, portanto, à leis provenientes de uma outra fonte e dá ao problema representativo um novo alcance; pois o poeta-músico se torna mestre do Tempo e assim é deixado a seus próprios recursos, a menos que a concepção dramática lhe impuser desde o início uma forma cênica determinada (assim como em Tristão e Os Mestre cantores). Se, então, ele não considerar a encenação como estando em seu poder antes de toda realização material, ele só poderá se apoiar sobre uma convenção estabelecida e se encontrar, por consequência, privado de um elemento de sugestão e de atividade que nada pode substituir, já que a convenção tradicional, longe de enriquecer sua visão, incontestavelmente lhe faz violência.

É em tão desfavoráveis condições que Wagner se encontrou para Parsifal e o Ring; de forma que a influência do princípio cênico atual, adotado pelo mestre, se revelará nessas duas obras primas mais claramente do que em Tristão e Os Mestres cantores.

As partituras de Parsifal e do Ring apresentam, cada uma, uma sequência de episódios que não constituem a ação dramática essencial. Mas enquanto que, por exemplo, em Os Mestres cantores a vida exterior só está lá para ser posta em oposição ao real conteúdo da expressão musical, no Ring é o desenvolvimento completo dessa vida que deve provocar o conflito na alma do herói e terminar na operação interior que provoca o desnudamento e a solução; disso vêm as dimensões colossais desse drama ${ }^{12}$.

Um tão grande desenvolvimento que se opera na alma do herói não é mais o resultado de uma série consecutivas de causas e efeitos, mas somente da viva constatação de um estado geral de sofrimento; e os eventos que trouxe-
12 Podemos a rigor imaginar que se o desenvolvimento completo dos personagens dos Mestres cantores tivesse sido a condição de existência da ação desse drama, Wagner teria que estendê-lo em vários dias de representação; da mesma forma que em sentido inverso, se o conflito na alma de Wotan pudesse operar-se unicamente pelo contraste entre a presença do deus e a vida exterior das outras personagens, o Ring se teria reduzido a proporções inferiores. 
ram esse sofrimento só tomam uma parte totalmente secundária à ação interior. Assim, o problema representativo de Parsifal difere daquele do Ring no fato de que a duração e a continuidade do drama são determinados pela duração e a continuidade do desenvolvimento psicológico do herói ao invés de depender dos eventos propriamente ditos. Nele, a idealidade do tempo musical é, portanto, incomparavelmente mais independente do que no Ring; pois a evolução interior, objeto do drama, é inteiramente de âmbito musical: sua duração é ilimitada em si. Por outro lado, o espetáculo que pretende provocar essa evolução é absolutamente indeterminado: só o sofrimento pode revelar a compaixão, mas há mil formas de sofrimento. Por consequência a ficção se reveste, em Parsifal, de um caráter total e particularmente arbitrário. Para evitar um afastamento muito grande entre a ficção e o alto alcance da expressão musical, era necessário situar o espetáculo em uma esfera de certa forma ideal, cujo ocasional uso de signos pudesse se generalizar espontaneamente e se colocar em relação com o mundo interior revelado. É o que Wagner fez; e nós sabemos, por exemplo, com qual maestria ele se apropriou de um sofrimento tradicional para identificá-lo, através da música, com o dos seus personagens. Conquanto, o problema representativo estava assim apenas afastado e não resolvido.

A duração musical é, no Ring, de uma grande complexidade. A vida humana, que lhe fornece as formas gerais e a continuidade, é constantemente conturbada pelo antropomorfismo mitológico de certos personagens. A epopeia se apropria bastante bem desse estado de coisas; o drama falado, forçado a reduzir bastante o seu alcance, não poderia estar mais envergonhado; mas a extrema facilidade com a qual a música pode exprimi-la cria para o poeta-músico um problema que, nós o veremos, é exclusivamente representativo.

A evolução interior na alma do deus Wotan se exprime tão bem pela parte episódica quanto nas passagens que lhe são especialmente consagradas. A existência pessoal de Wotan e o resto do espetáculo são apenas duas faces de uma mesma coisa. Do ponto de vista puramente material são os eventos que determinam uma evolução especial nessa existência; mas, vistos do idealismo imanente à forma poético-musical, esses eventos se veem como sendo eles próprios a evolução: o doloroso privilégio de um deus é de exteriorizar assim a sua alma e de poder contemplá-la. Como flexibilizar suficientemente o tempo musical para encontrar uma média entre a sua completa e ideal independência e a sua relativa submissão à ordem realista dos fatos?

Os episódios ganharam, no Ring, devido ao gênio particular de Wagner, uma intensidade e uma clareza extraordinária. No entanto são as parte nas quais a idealidade do tempo musical é o mais estreitamente submissa à or- 
dem realista dos fatos que as afasta da livre expressão que outras passagens podem se revestir. As suas intensidades são atribuíveis unicamente ao treinamento do gênio, ou elas fazem parte da ação dramática? Um espetáculo que é de certa forma a objetivação da vida interior de um deus não poderia evidentemente ser muito rico: a amplidão de um tal personagem se exprime em função da intensidade da sua criação. Mas, por outro lado, o espaço indispensável consagrado à existência pessoal de Wotan permanece absolutamente indeterminado; nada pode ditar suas dimensões nem sua continuidade: é o domínio da presença absoluta e, quanto mais evidente for o personagem, mais clara a oposição material e a ideal identidade das duas faces do drama.

Diante dessas condições de aparência contraditória, Wagner se encontrou preso a um princípio representativo rígido, fixado em uma impotente convenção realista. A visão do mestre poderia acomodar-se, como nós o vimos, com o realismo na continuidade e na forma; a rigidez unicamente se opunha ao caráter da sua concepção; e ainda assim era por um extremo realismo que Wagner queria a mobilidade. A ideal flexibilidade de um espetáculo expressivo é uma noção que parece nunca ter perpassado sua cabeça ${ }^{13}$. Para ele, o que se passa sobre a cena se passa sempre em realidade. O Ring é um espetáculo de paisagem; nele, a natureza, em todos os aspectos, se desdobra de uma ponta à outra do drama. O papel assinalado por Wagner ao paisagista (no Kunstwerk der Zukunft) parece, do ponto de vista do mestre, encontrar sua mais rica aplicação. Wagner é, contudo, um artista grande demais para procurar ilustrar, por uma obra de arte, princípios teóricos; é bem mais por estes últimos que ele procura esclarecer sozinho a irresistível, mas ainda pouco consciente, impulsão artística. Se, reiteradamente, ele considera a pintura cenográfica como o plano de fundo que fornece a paisagem ao ator, é todavia - quando ele chega na concepção dramática de fato - o homem e a natureza presos um ao outro, o ator mergulhado no tablado cênico, que pode satisfazê-lo. Ora, os fenômenos da natureza são eminentemente móveis e o ser humano misturando se neles participa da sua mobilidade. Ele se encontra, dessa forma, em uma relação harmoniosa. O ator e o cenário, para unirem-se em uma relação correspondente, nós o sabemos, um deve sacrificar uma parte da sua vida independente e, o outro, uma porção considerável do seu uso do signo (multiplicidade do detalhe). O espetáculo adquire assim um caráter expressivo que influencia a concepção dramática, pois o poeta-músico, certo de que ele é perfeitamente compreendido pela encenação, pode se permitir tudo. A oposição entre a Expressão e o Signo fica sendo a única lei restritiva e condutora para a feitura da partitura. Um drama onde os fenômenos da natureza realizam um papel tão preponderante quando no Ring não é,
13 Parsifal apresenta uma tendência bastante sensível em direção a essa idealidade; tendência que leva, não obstante, mais à ficção escolhida do que a uma evolução representativa no mestre. 
portanto, compatível com o princípio representativo adotado por Richard Wagner. Se, contudo, a impulsão do gênio se torna irresistível, ela enfrenta todas as convenções, rompe todas as barreiras. É assim para o Ring: Wagner não tomou consciência das convenções adotadas; ele quis transportar para a cena tradicional os fenômenos da natureza, conservando um realismo impraticável. Em uma palavra, o mestre acreditou-se livre, representativamente, enquanto que ele ignorava o segredo dessa liberdade. A partitura do seu drama carrega a impressão profunda dessa contradição original que, enquanto ela não for reconhecida, colocará obstáculos a toda representação correta.

A intensidade episódica de que falamos, submetida à continuidade realista dos fatos, é a única atingida por esse estado de coisas, já que somente nela o mestre abusou da sua independência. Por outro lado, o domínio indeterminado da absoluta presença musical (a outra face da ação) correspondia bem demais ao poder de um Richard Wagner para ser influenciada na sua concepção e na sua feitura por quaisquer considerações secundárias. Tomado independentemente dos motivos episódicos, esse elemento de presença absoluta atinge no Ring um poder único cuja história da arte sem dúvida não fornece até aqui nenhum equivalente ${ }^{14}$. Portanto, essa porção da expressão, permanecendo estranha pela sua própria natureza ao supremo realismo cenográfico que presidia a concepção do resto do drama, negligenciava por esse fato toda atividade cênica possível, e veio a constituir uma sucessão de interrupções na forma representativa geral. Quando, então, eu falo de interrupções na forma representativa, eu estou me referindo somente um tipo de combinação poético-musical perfeitamente legítima em si, mas que o princípio cênico adotado pelo mestre não comporta e ao qual ele permanece estranho, o que constitui incontestavelmente uma interrupção na integridade da representação.

Nó vimos assim, no Ring, de um lado um realismo episódico impraticável por causa da sua natureza particular, e do outro uma independência poético-musical em contradição com a forma representativa adotada por ambos ${ }^{15}$.

O que nós observamos na partitura do Ring se aplica em alguma medida àquela de Parsifal, ainda que a situação representativa deste último drama seja muito menos complexa. A absoluta presença musical é aqui a ordenadora da concepção poética no seu conjunto, de forma que a ficção realista deve se reduzir ao seu mínimo senão o afastamento entre essa ficção e o alto alcance da expressão musical, tornando-se muito considerável, destruiria a relação comum entre elas. Tudo o que o mestre pôde colocar em jogo para esse objetivo ele o fez; não há quase nenhum minuto de ficção cujo realismo não seja, de uma forma ou de outra, amortecido e idealizado. Wagner faz dizer à Gurnemanz: "Zum Raum wird hier die Zeit" ["aqui o tempo se torna espaço"];
14 Compreenderemos facilmente que por episódios eu entendo as passagens onde as criaturas do deus parecem agir dos seus próprios movimentos, e por presença absoluta aquelas onde esses personagens são apenas os portadores de uma expressão que lhes é imposta pela vida independente de Wotan. Wotan, ele, apenas toca ligeiramente o episódio e a sua aparição institui sobre a cena quase sempre o elemento de presença absoluta.

15 Se nós quiséssemos penetrar mais adiante, com esses dados, na concepção do mestre, nós chegaríamos infalivelmente a nos perder. É como artista, consciente do poder das suas convicções de artista, que é preciso abordar o problema técnico. 
aqui está para o espaço; e quando o objeto desse paradoxo se desvia para um outro gênero de espetáculo é esta a mágica mais característica que o mestre recorre para continuar a confundir o tempo e o espaço. A relações dos personagens entre eles são de natureza ideal e existem fora de toda duração, encarnando nesse sentido de uma maneira contundente e indecisa a doutrina da metempsicose. As noções mais elementares, tais como a Morte, o Sono, o Sofrimento psicológico, etc., ganham de uma só vez, por esse estado de coisas, uma significação transcendente. A intervenção indispensável das relações de causa a efeito está quase inteiramente regulada fora da ação representativa, e confinada ao relato - à maneira do drama antigo; e isso no objetivo manifesto de deixar o maior relevo possível aos sintomas da evolução interior na alma de Parsifal, efeito direto do espetáculo. Quanto à encenação propriamente dita, Wagner fez o impossível para colocá-la de acordo com a sua concepção dramática: o cenário se desenvolve e se transforma repetidamente sob os olhos do espectador; a luz do dia é até mesmo, as vezes, na dependência de um princípio superior à suas leis, princípio divino ou diabólico. Mas essa mobilidade, quase ideal, permanece, contudo, profundamente realista, no sentido de que os personagens do drama nela participam conscientemente, e que eles conseguem até mesmo provocá-la sob o império do êxtase ou de uma inspiração sobrenatural.

E aí está o ponto de contato entre a concepção cênica do Ring e aquela de Parsifal. Apesar das aparências, elas são ambas realistas; apenas, as exigências de uma são de natureza positivamente impraticável, enquanto que àquelas da outra - Parsifal —, sendo sustentadas pelo caráter eminentemente ideal das condições representativas onde se encontram os personagens, como tal, podem, sem fazer nenhuma violência às intenções do mestre, se aproximar da forma expressiva. De fato, os personagens de Parsifal são, de certa forma, eles próprios elementos de expressão; para nós, eles nos são apresentados apenas sob esse aspecto e o autor os libertou nesse objetivo de toda obrigação realista, de onde resulta que as suas participações no estado do espetáculo são elas mesmas arrastadas para o domínio da pura expressão.

Desse ponto de vista, como em todos os outros, o drama de Parsifal corresponde ao seu título "Bühnenweihfestspiel" ["Festival cênico sagrado"]: ele consagra a cena onde ele é representado. Wagner, na sua última obra, chegou ao milagre efetivo: ele venceu o obstáculo representativo com armas superiores a todos os princípio técnicos.

Os quatro dramas de que nós tratamos apresentam quatro combinações distintas: Tristão pede a redução máxima da atividade representacional. A feitura do seu texto poético-musical é, nesse aspecto, conforme a intenção 
dramática ideal; e as indicações cenográficas que precedem cada um dos atos têm mais relação com a leitura do poema do que com a sua representação. Nesse drama, a concepção cênica do mestre mostrou-se impotente para entravar o livre desenvolvimento das suas intenções poético-musicais, e a forma expressiva do espetáculo pôde se manifestar sem de fato lhes fazer violência. A harmonia se estabelece, assim, pela própria origem do drama e, coisa curiosa, independente do autor.

O princípio cênico também não pôde agir diretamente sobre a concepção de Os Mestres cantores, já que a ação essencial desse drama consiste na intencional oposição entre a intensidade da expressão musical e o sentido simplesmente inteligível da ficção representativa. Segue que são os personagens que o realismo favorece para brilhar na cenografia, e essa combinação não tem nada de contrária ao grau de expressão que podem comportar as disposições espaciais escolhidas pelo autor. Portanto, aqui, como para Tristão, mas por outras razões, a concepção poético-musical é independente de um princípio cênico qualquer, e a representação pode, em certa medida, ser realizada integralmente.

Nós acabamos de ver que Parsifal constitui, do ponto de vista representacional, a vitória da Ideia sobre as resistências dos procedimentos técnicos; de forma que aplicando-lhe o princípio expressivo da encenação nós finalizaríamos o trabalho do próprio mestre.

Poderíamos dizer que esses três dramas servem de exemplo para os princípios teóricos que expus na parte anterior desse estudo? Sim, em um sentido: eles testemunham, cada um a sua maneira, o soberano poder do desejo musical que faz nascer o drama; eles demonstram que esse desejo, fecundado pela fantasia poética, se desenvolve do interior para o exterior em uma forma necessariamente orgânica. Mas essa demonstração é negativa, já que ela apenas prova que o dramaturgo, no mesmo momento em que a sua visão cênica poderia ser estranha à natureza dos meios poético-musicais de que ele dispõe, pode ser levado pelo poder destes últimos até uma independência que, somente em certos casos, liberta a sua partitura da influência paralisante exercida por um princípio representativo heterogêneo.

Ora, nesse aspecto, o dramaturgo não se encontrou sob a influência sugestiva, no melhor dos casos, que a plena consciência da sua liberdade representativa deveria exercer. Se ele pôde, momentaneamente, sacudir a manta rígida da convenção cênica atual, é por excesso de gênio e graças à natureza dos meios poético-musicais. Mas, pelo Ring, nós temos a prova da inconstância de tal independência quando ela não é o resultado de uma afirmação técnica.

A partitura do Ring tende em parte às três combinações precedentes: as passagens de absoluta presença musical estão naturalmente de acordo com 
Tristão; a Götterdämmerung se aproxima de Os Mestres cantores pelo seu princípio; e o idealismo de Parsifal se faz notar, discretamente, em várias passagens ao curso do drama. Ora, quanto mais cada uma dessas combinações puderem constituir por elas mesmas um conjunto harmonioso, mais a sua mistura sucessiva em uma convenção cênica, incompatível com todas elas e que impede que o encenador consiga dar suporte a cada uma em particular, se torna desfavorável para a integridade da obra. Aliás, o obstáculo essencial é, como nós vimos, o tipo de realismo que o mestre acreditou poder tornar independente do princípio cênico que ele, contudo, havia adotado.

Em última análise, o Ring sofre, portanto, de um erro técnico na sua concepção representativa; e dos dramas do segundo período, ele é o único que não podemos por em cena sem comprometimento. Se o esplendor absoluto da sua partitura fosse infirmada por uma representação que descobrisse o erro ao invés de neutralizá-lo, ela concorreria para restabelecer para com o público, através da nova encenação, uma harmonia que só poderíamos conceber em pleno conhecimento de causa.

No apêndice que encerra esse estudo eu darei as noções gerais sobre as quais é preciso se apoiar para compor a encenação do Ring. E mais, um projeto sumário para a encenação de Tristão mostrará de que forma o princípio expressivo pode se aplicar à concepção do mestre.

Resumamos agora brevemente as noções que nós adquirimos no decorrer deste capítulo.

As partituras de Richard Wagner são obras de arte essencialmente alemãs e carregam, portanto, no mais alto grau o caráter distintivo das produções dessa raça: elas resultam de um desejo que não tem a forma como objetivo. Mas em qualidade de obra dramática elas ainda têm que se transportar sobre a cena. Para julgar então a congruência das suas formas representativas, é preciso que no artista a cultura do olho esteja em relação harmoniosa com o desejo íntimo cuja prova é a partitura. A própria atitude do mestre diante da representação dos seus dramas, a instalação da cena de Bayreuth para o drama do Ring e os escritos que a ele se relacionam nos convenceu de que em Wagner essa relação era defeituosa. De fato, os recursos da cena moderna não são compatíveis com o emprego da música e o mestre, adotando-os, teve que aumentar sua influência. Apoiado sobre princípios teóricos estabelecidos na primeira parte, nós pudemos determinar o caráter muito complexo dessa influência e assinalar o seu traço nos quatro últimos dramas do mestre.

Resta-nos ver como o Alemão pode adquirir o sentido que ainda lhe faz falta, como ele pode dar à sua produção nacional uma forma representativa 
digna dela e, completando assim a resplandecência do maravilhoso tesouro de que Richard Wagner é testemunha, expandir soberanamente a sua influência exteriormente. 